\title{
Wet Days in the Dry Quarter of the Alcântara Launch Center Region: Observational Features
}

\author{
Paulo César Silva da Costa ${ }^{1}$, Marcos Daisuke Oyama2,*, Rosa de Fátima Cruz Marques²
}

\author{
Costa PCS (D) https://orcid.org/0000-0002-4996-0665 \\ Oyama MD (10) https://orcid.org/0000-0001-8720-912X \\ Marques RFC (iD) https://orcid.org/0000-0002-7877-7990
}

\author{
How to cite \\ Costa PCS; Oyama MD; Marques RFC (2019) Wet Days \\ in the Dry Quarter of the Alcântara Launch Center Region: \\ Observational Features. J Aerosp Technol Manag, 11: e3219. \\ https://doi.org/10.5028/jatm.v11.1063
}

\begin{abstract}
Precipitation events are infrequent in the dry quarter (SON) of the Alcântara Launch Center (Centro de Lançamento de Alcântara, CLA], the main launch site of the Brazilian Space Program. However, their occurrence could be a risk for activities during launch missions. In this work, the observational features of wet days (daily precipitation total $\geq 1 \mathrm{~mm} /$ day) in the dry quarter of the CLA region were studied. Daily precipitation totals over the course of 37 years (1979-2016, except 2006), outgoing longwave radiation (OLR) data and ERA-Interim reanalysis data were used. On average, in the dry quarter, there were 9 wet days, which accumulated $32 \mathrm{~mm}$. The number and quarterly precipitation total of wet days showed pronounced interannual variability. This variability was negatively and significantly correlated with the interhemispheric sea surface temperature anomalies gradient in the Atlantic Ocean and the wind speed at $925 \mathrm{hPa}$ over the CLA region. Based on a theoretical distribution (lognormal), the probability of occurrence of heavy precipitation days (daily total $\geq 10 \mathrm{~mm} /$ day) was only $0.5 \%$. For days with heavy precipitation and deep convection (OLR $\leq 230 \mathrm{~W} \cdot \mathrm{m}^{-2}$ ), over a large area along the northeastern coast of South America including the CLA region, negative OLR differences (from the mean) and the strengthening of favorable conditions for deep convection were found. The large-scale organization of the convective activity and atmospheric features for higher precipitation events obtained in this work could be helpful for nowcasting and short-range weather forecasting during launch missions at the CLA.
\end{abstract}

KEYWORDS: Aerospace meteorology, Precipitation, Deep convection.

\section{INTRODUCTION}

The Alcântara Launch Center (Centro de Lançamento de Alcântara, CLA), located on the northern coast of Brazil (NCB), is the main launch site of the Brazilian Space Program (Fig. 1a). At CLA, aerospace vehicles designed and developed by the Instituto de Aeronaútica e Espaço are launched. During launch missions, the ideal conditions for activities at CLA, particularly when the aerospace vehicle or its parts are outside the tower shelter (Torre Móvel de Integração) and thus directly exposed to surface atmospheric conditions, include the absence of precipitation, lightning and strong surface winds (Marques and Fisch 2005). In the dry quarter of CLA, which corresponds to the austral spring (September to November, SON), the limiting factor for these activities, including the determination of the launch window, is usually the presence of strong surface winds. In this quarter the average surface wind speed is higher and precipitation events are infrequent (Pereira et al. 2002; Barros 2008).

Precipitation events over the CLA region in the dry quarter, albeit infrequent, could be a risk for activities during launch missions. For instance, in the launch missions called Operação Maracati II (VSB-30; 16 Nov to 14 Dec 2010) (Souza 2011) and Operação

1.Departamento de Controle do Espaço Aéreo - Centro Integrado de Meteorologia Aeronáutica - Centro Meteorológico Integrado - Rio de Janeiro/RJ - Brazil.

2.Departamento de Ciência e Tecnologia Aeroespacial - Instituto de Aeronáutica e Espaço - Divisão de Ciências Atmosféricas - São José dos Campos/SP - Brazil.

*Correspondence author: marcos.oyama@ymail.com

Received: Sep. 5, 2018 | Accepted: Nov. 27, 2018

Section Editor: Willian Vaughan 
Iguaíba (VS-30/ORION V10; 18 Nov to 14 Dec 2012) (Souza 2013a), the occurrence of several light/moderate rain events was reported. Although they did not impact the launch activities, their occurrence shows the need for studies on precipitation events in the dry quarter to help the meteorological support and decision-making during launch missions. It is worth mentioning that the problem is not restricted to light/moderate rain events, because severe weather events can occur over the CLA region in the dry quarter. For instance, on 20 October 2011 heavy precipitation was reported in numerous localities in the state of Maranhão, including CLA and São Luís, the state capital (Marques and Souza 2015). In São Luís, the precipitation event led to flooding in several areas of the city (Jornal Pequeno 2011).

(a)

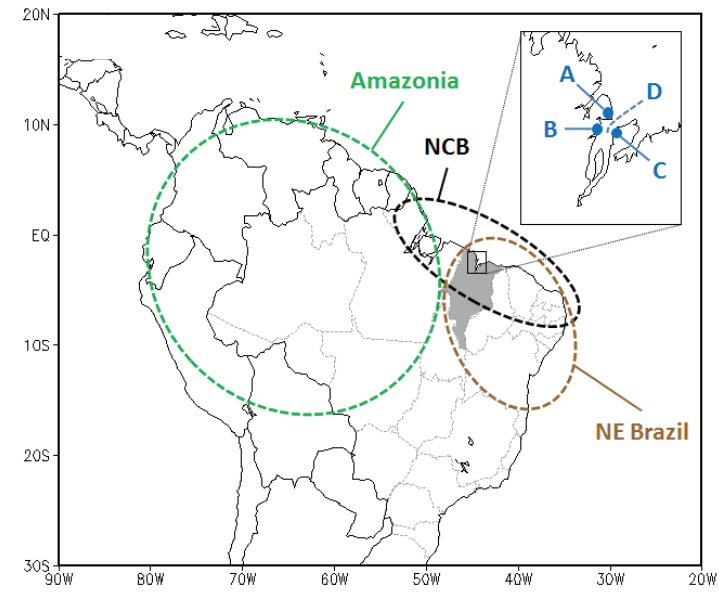

(b)

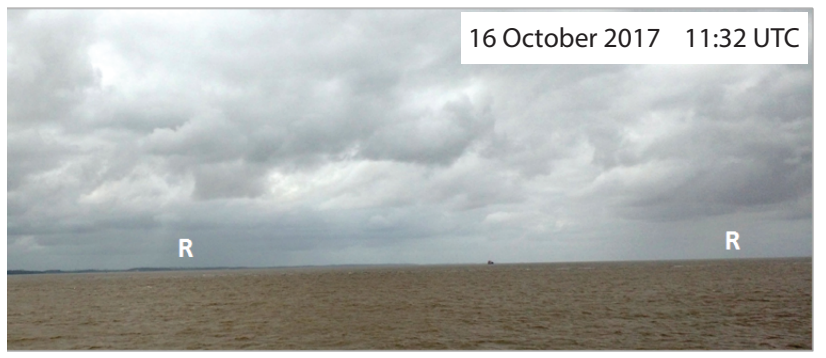

Figure 1. (a) The boundaries of Brazilian states are indicated by gray dotted lines. The State of Maranhão is shaded in gray. Dashed circles show the approximately location of the NCB (black), Northeast Brazil (brown) and Amazonia (green). The box-like region that includes the CLA is zoomed in and the approximately location of the CLA (A), Cujupe (B), São Luís (C) and São Marcos Bay (D) is shown; (b) Photograph of the west bank of São Marcos Bay, where the CLA region is located, taken during the crossing of São Luís to Cujupe by ferryboat. Areas under light precipitation are indicated with the letter "R". These areas occur under extensive cloud cover.

Therefore this work focuses on precipitation over the CLA region in the dry quarter, for which the main observational features are already known.

- On average, the quarterly total precipitation is approximately 30-40 mm (Pereira et al. 2002; Barros 2008) and there are only 8 days with precipitation in the quarter (Souza 2013b). These low values could be explained by the presence in the dry quarter of atmospheric conditions that are unfavorable for convection deepening, such as the low-level large-scale subsidence over Northeast Brazil (Marques et al. 1983) and the dry mid-level layer over the CLA region (Oliveira and Oyama 2009).

- Precipitation events in the dry quarter can be grouped into two broad categories:

- The first category contains drizzle or light rain events, which occur most often during the morning. These events are more frequent between 1200 to 1500 UTC and characterized by low totals, short duration, low intensity $\left(<0.5 \mathrm{~mm} \cdot \mathrm{h}^{-1}\right)$ (Barros 2008) and an irregular spatial distribution (Fig. 1b). They are related to the presence of a vast stratiform low-top cloudiness over the west margin of São Marcos Bay in the early morning that lasts for some hours (Souza 2016). Light stratiform precipitation and warm rain are likely related to events in this category (Yang and Smith 2008; Calheiros and Machado 2014).

- The second category contains events characterized by higher precipitation totals, intensity and duration. These events may be related to the occurrence of mesoscale and large-scale systems that affect the NCB directly, such as squall lines, convective mesoscale complexes and easterly waves, or remotely, such as the South Atlantic Convergence Zone and frontal systems (Machado et al. 1998; Coutinho and Fisch 2007; Tavares 2008; Barros and Oyama 2010; Marques and Souza 2015). Moderate to heavy stratiform and convective precipitation are likely related to events in this category (Yang and Smith 2008; Calheiros and Machado 2014). The low-level convergence over the CLA provided 
by these transient systems could overcome the unfavorable conditions for convection deepening in the dry quarter and increase the probability of precipitation occurrence (Oyama and Oliveira 2015). The higher total precipitation reported by Barros (2008) in the early evening (2100 to 0000 UTC) could result from events in this category.

- The precipitation features in the dry quarter, such as the quarterly total, show marked inter-annual variability (Souza 2013b). For the northern coast of Northeast Brazil (which includes the CLA region), this variability does not seem to be related to El Niño or La Niña episodes in the equatorial Pacific Ocean (Oliveira 2014).

All previous works that obtained the average precipitation features in the dry quarter considered events in both categories. However, the number of events in the first category is likely to be underestimated for two reasons: the low total precipitation, which may be not sufficient to be recorded (by a rain gauge), and the irregular spatial distribution of the precipitation. The probability of missing a precipitation event in the second category tends to be low due to the higher precipitation totals and larger affected areas. Therefore, to minimize the uncertainty related to events in the first category, only wet days, i.e., days with a total $\geq 1 \mathrm{~mm} /$ day (Tank et al. 2009), are considered in this work. Although wet days are mostly comprised by events of the second category, they also include the light rain events with higher totals from the first category.

The precipitation features in the dry quarter obtained previously are based on different datasets covering distinct and relatively short periods. Pereira et al. (2002) and Barros (2008) used rain gauge data collected at CLA from 1993-1997 (7 years) and 1993-2006 (14 years), respectively, while Souza (2013b) used data from the Global Precipitation Climatology Project (GPCP) from 1997-2012 (16 years). As the results of these previous studies could be dependent on the specific data source used, the first objective of this work is to verify these results by obtaining the main features of wet days using a single and longer precipitation dataset ( $>30$ years), which also permits the computation of statistics closer to the climatological normal.

The factors that influence the inter-annual variability of precipitation features in the dry quarter remain an open question. To address this point, the second objective is to initially confirm that the inter-annual variability of wet days features is not significantly related to the occurrence of El Niño or La Niña episodes (Oliveira 2014). Then the relationships between the interannual variability and other possible factors, such as sea surface temperature anomalies (SSTA) in the tropical Atlantic Ocean and low-level flow over the CLA region (Marques and Oyama 2015) will be verified.

The third objective addresses the wet days with highest totals: the heavy precipitation days, i.e., days with a total $\geq 10 \mathrm{~mm} /$ day (Tank et al. 2009). This subset of wet days is widely used in climate studies (e.g., Santos and Oliveira 2017). Initially, the probability of occurrence of heavy precipitation days in the dry quarter is computed by using a theoretical statistical distribution. Then, for heavy precipitation days with deep convection over the CLA region - hereafter referred to as days with heavy precipitation and deep convection - the average large-scale horizontal pattern of convective activity and atmospheric conditions is obtained, expanding the study of Marques and Souza (2015) of two heavy precipitation events over the CLA during the dry quarter.

In the next section of this work, the data and methodology are presented. Then, the results from the first (characterization of wet days), second (factors related to the inter-annual variability of wet days features) and third objectives (probability of occurrence of heavy precipitation days and convective activity and atmospheric conditions for days with heavy precipitation and deep convection) are presented sequentially in separate sections. Finally, concluding remarks are given.

\section{DATA AND METHODOLOGY}

Daily precipitation totals from the Climate Prediction Center (CPC)/National Oceanic and Atmospheric Administration (NOAA) for the SON quarter over the course of 37 years, i.e., 1979-2005 and 2007-2016, are used. These data are based on rain gauge measurements gridded on a regular $0.5^{\circ} \times 0.5^{\circ}$ mesh using an optimal interpolation technique (Xie et al. 2007; Silva et al. 2007b). The daily total for the CLA region is calculated as the area-mean over the 4 grid points that surround CLA (Pinheiro and Oyama 2013); therefore, the CLA region is defined in this work as the $1^{\circ} \times 1^{\circ}$ area centered at $2.5^{\circ} \mathrm{S}$ and $44.5^{\circ} \mathrm{W}$. The SON quarter in 2006 is excluded because its quarterly total is clearly unrealistic (> 10 times the mean). In this work, as mentioned previously, only wet (daily total $\geq 1 \mathrm{~mm} /$ day) and heavy precipitation days (daily total $\geq 10 \mathrm{~mm} /$ day) are considered. 
For the SON quarter of each year, the quarterly total precipitation of wet days (PWET) and the number of wet days (NWET) are obtained. Then, considering the 37 values of PWET and NWET (one value per year), mean $(\mu)$ and standard deviation $(\sigma)$ are computed for both variables. For each year, the normalized value $\left(f^{\star}\right)$ is given by Eq. 1 :

$$
f^{*}=\frac{f-\mu_{f}}{\sigma_{f}}
$$

where $f=$ PWET or NWET. Normalized values are used in the analysis of the interannual variability.

The relationships between the inter-annual variability of wet days features (PWET and NWET) and four factors, i.e., two oceanic indices, NINO3 (Trenberth 1997) and the interhemispheric SSTA gradient in the Atlantic Ocean (GRAD) (Andreoli and Kayano 2004), and two variables related to the low-level flow, wind speed (MAG) and direction (DIR) at $925 \mathrm{hPa}$ over an area representative of the CLA region, are evaluated. These factors affect the interannual variability of precipitation for the CLA in the rainiest months (Marques and Fortes 2012; Marques and Correa 2014; Pereira and Marques 2014). Their monthly values are computed using the same datasets and methodologies described in Marques and Oyama (2015). The degree of association between the time series of the quarterly (SON) mean of a given factor and the time series of PWET or NWET is assessed by the Pearson coefficient of correlation. Its statistical significance is evaluated using Student's t-test at the $90 \%$ level.

Daily outgoing longwave radiation (OLR) data from the Earth System Research Laboratory/NOAA are used (Lee et al. 2014). The data are available on a regular $1^{\circ} \times 1^{\circ}$ mesh for the period 1979-2012. The OLR value for the CLA region is computed as the area-mean over the two grid points centered at $2^{\circ} \mathrm{S}, 44.5^{\circ} \mathrm{W}$ and $3^{\circ} \mathrm{S}, 44.5^{\circ} \mathrm{W}$ because CLA is located close to the interface between these grid points.

Large-scale atmospheric conditions are obtained from the ERA-Interim reanalysis dataset (Dee et al. 2011). Daily values are defined as the mean of the four analysis values $(0000,0600,1200$ and $1800 \mathrm{UTC})$. The data are available on a regular $0.75^{\circ} \times 0.75^{\circ}$ mesh for the period 1979-present. Fields of atmospheric circulation and divergence at 850 and $250 \mathrm{hPa}$ and specific humidity at $500 \mathrm{hPa}$ are used in this work.

The horizontal pattern of convective activity (OLR data) and related atmospheric conditions (reanalysis data) are obtained from 15 days with heavy precipitation, i.e., daily total $\geq 10 \mathrm{~mm}$ /day, and deep convection, i.e., OLR over the CLA region $\leq 230 \mathrm{~W} \cdot \mathrm{m}^{-2}$ (Ferreira et al. 2005). The mean fields of days with heavy precipitation and deep convection are compared to the quarterly (SON) mean (1979-2012 for OLR; 1979-2017 for reanalysis). The statistical significance of the differences is evaluated using Student's t-test at the 95\% level.

The normal, log-normal, gamma, exponential and Weibull distributions are used in the statistical modeling (Naghettini and Pinto 2007). These are usual distributions that represent daily precipitation totals (e.g., Catalunha et al. 2002). The distribution parameters are estimated using the maximum likelihood method (e.g., Sansigolo 2008) using the Software Minitab®. Three tests of goodness of fit are used: Anderson-Darling (AD), chi-square $\left(\chi^{2}\right)$ and Kolmogorov-Smirnov (KS). Statistical significance at the 95\% level is adopted. After the theoretical distribution that fits the observed data is found, the probability of occurrence of a day with $X$ - daily total or exceedance, defined here as the daily precipitation total above the threshold of $1 \mathrm{~mm} /$ day - greater than $x$ is calculated using Eq. 2 (Silva et al. $2007 \mathrm{a}$ ):

$$
P(X>x)=[1-\Phi(x)] \cdot \frac{n}{N}
$$

where $\Phi(\mathrm{x})$ is the probability of $X$ below $x$ according to the theoretical distribution; $n$ is the number of days used to fit the theoretical distribution; and $\mathrm{N}$ is the total number of days ( $=37$ years $\times 91$ days in $\mathrm{SON}=3367$ days $)$.

\section{RESULTS}

\section{FEATURES OF WET DAYS}

Statistics of NWET and PWET for the dry quarter in CLA are shown in Table 1. On average in the dry quarter, from the mean values, there are 9 wet days, which accumulate $32 \mathrm{~mm}$. Median values are lower - 7 wet days and $25 \mathrm{~mm}-$ due to the positive 
skewness of NWET and PWET distributions. These distributions also show considerable spread: for NWET, the coefficient of variation and the quartile coefficient of dispersion are $83 \%$ and $43 \%$, respectively; for PWET, 49\% and 69\%. In November, the number and especially the monthly total of wet days are higher than in other months (not shown). These features agree in general with those obtained by Pereira et al. (2002), Barros (2008) and Souza (2013b) using different and shorter duration datasets.

Table 1. Statistics of the number and the total precipitation of wet days for the entire quarter (SON). Period: 1979-2016, except 2006 (37 years).

\begin{tabular}{|c|c|c|}
\hline Statistics & Number of wet days & Total precipitation of wet days \\
\hline Mean & 8.7 & 31.6 \\
\hline Standard deviation & 7.2 & 15.6 \\
\hline First quartile (Q1) & 4 & 7.9 \\
\hline Second (median) quartile (Q2) & 7 & 24.7 \\
\hline Third quartile (Q3) & 10 & 42.2 \\
\hline Interquartile range (Q3 - Q1) & 6 & 34.3 \\
\hline
\end{tabular}

The number of cases with consecutive wet days is shown in Fig. 2. The number decreases steeply as the number of consecutive wet days increases. The majority of cases (72\%) correspond to isolated wet days. The remainder (28\%) is distributed among cases with 2 to 5 consecutive wet days. The cases with 4 and 5 consecutive wet days are rare: only 7 cases in 37 years. When these cases occur, PWET and NWET are well above mean. The existence of a considerable number of cases with consecutive wet days suggests that favorable conditions for precipitation occurrence in the dry quarter could persist for several days.

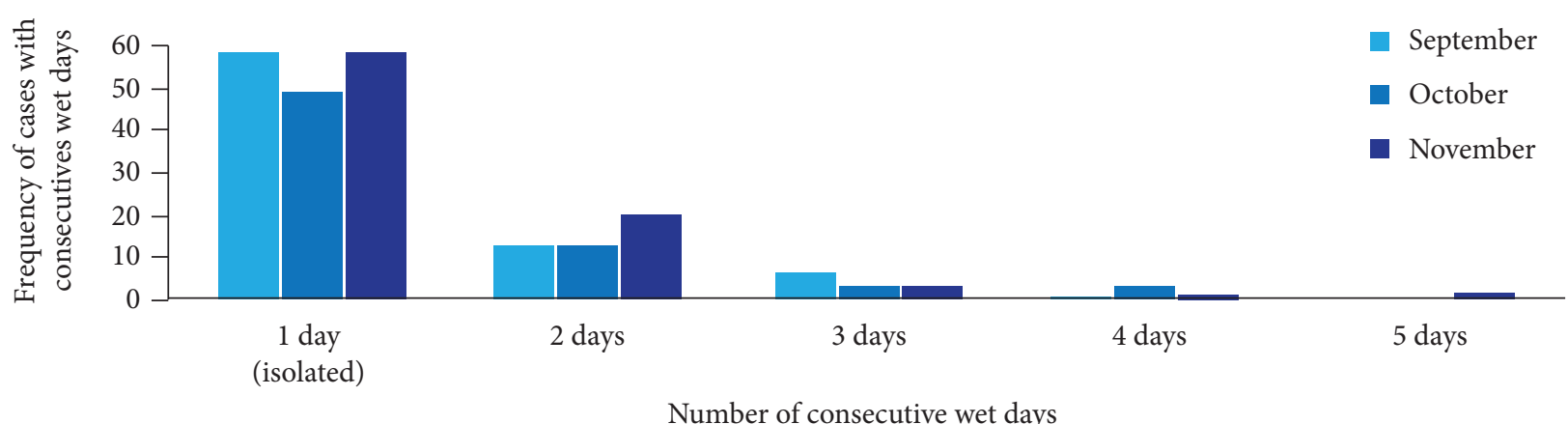

Figure 2. Number of cases with consecutive wet days for months of the dry quarter (September, October and November]. Period: 1979-2016, except 2006 (37 years).

In addition, in the dry quarter, the duration of dry spells - continuous periods without wet days (or consecutive dry days) (Tank et al. 2009) - is extremely variable (not shown), ratifying Barros (2008). The durations of the longest dry spells are usually 1-2 months. Rarely, a dry spell could last for more than 2 months. For instance, in 1981 there was a dry spell of 76 days, which illustrates how long unfavorable conditions for precipitation occurrence can persist in the dry quarter.

\section{INTERANNUAL VARIABILITY}

The time series of normalized anomalies of PWET and NWET, computed according to Eq. 1, are shown in Fig. 3. Both time series show pronounced interannual variability, which confirms the results of Souza (2013b), and a slight negative trend. An opposite non-significant trend was found by Oyama and Oliveira (2016) for the number of extreme precipitation events over the CLA region using CPC/NOAA data. The significance of the negative trend is not addressed further because it could be related either to longer climatic variabilities or to the decrease in the number of stations used to obtain the CPC/NOAA data over time 
(Silva et al. 2007b; Pinheiro and Oyama 2013). Regarding the magnitude of the anomalies, higher positive anomalies are found before 1990 (in 1984 and 1989 for PWET and NWET, and in 1986 for NWET).

The time series of PWET and NWET seem to be in-phase in many periods (Fig. 3). To check this phase relation, the dispersion diagram between PWET and NWET is shown in Fig. 4. Clearly, there is linear and positive correlation between these two variables $(r=+0.82$ ); i.e., high (low) NWET is related to high (low) PWET. For more than $70 \%$ of the considered years, the PWET and NWET anomalies have the same sign. This is particularly clear for the years when the magnitude of anomalies is higher than the standard deviation for both variables (1979, 1981, 1984, 1986, 1989 and 1992).

The correlations between wet days features - PWET and NWET - and the four factors - NINO3, GRAD, MAG and DIR - are shown in Table 2. For PWET and NWET, the linear correlations are not statistically significant for NINO3, which confirms the results of Oliveira (2014), and DIR, but the linear correlations are significant for GRAD and MAG. Above-mean (below-mean) values of PWET and NWET are significantly related to southward (northward) GRAD, i.e., South Atlantic Ocean with positive (negative) SST anomalies and/or North Atlantic Ocean with negative (positive) SST anomalies, and weak (strong) low-level wind over the CLA region. These relationships agree with the results of Marques and Oyama (2015) for the rainy quarter in the CLA region. Although the linear correlations with GRAD and MAG are significant, the fraction of explained variance (measured by the coefficient of determination, $r^{2}$ ) is rather limited: $9 \%$ to $10 \%$ for PWET and $15 \%$ to $27 \%$ for NWET. The majority of variance

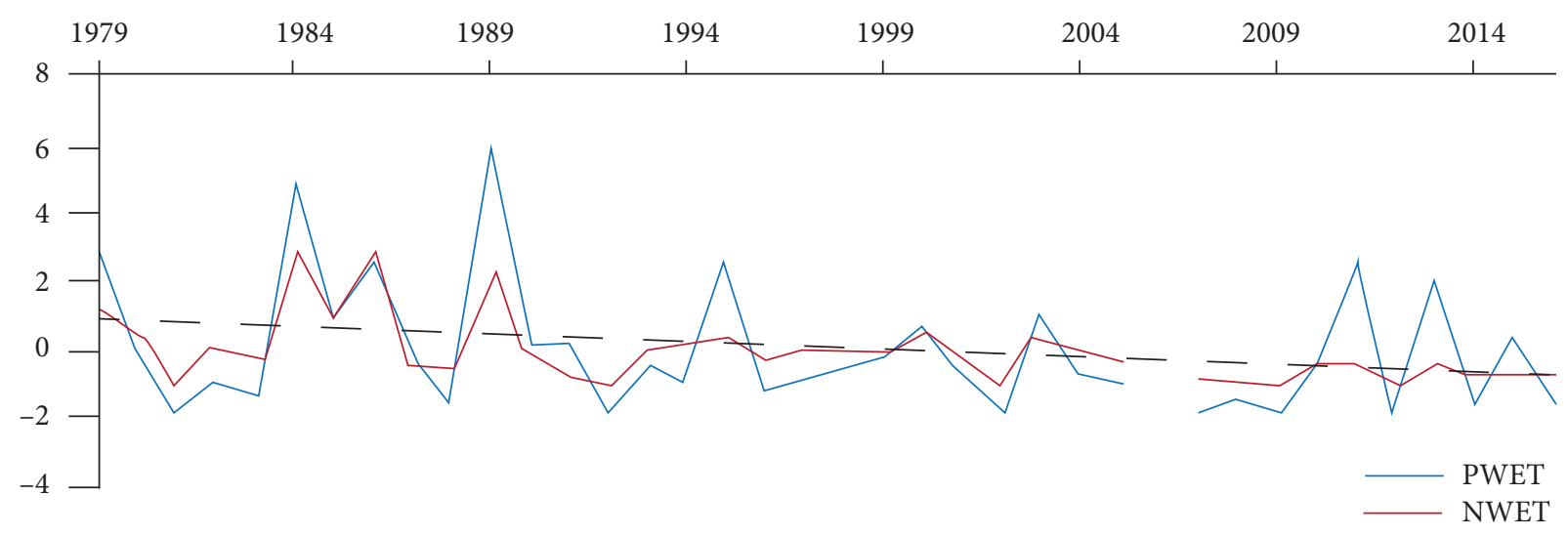

Figure 3. Time series of normalized values of PWET (blue) and NWET (red). In the vertical axis, one unit is equivalent to the standard deviation. The regression lines for PWET and NWET are nearly identical and are indicated by the dashed black line. Period: 1979-2016, except 2006 [37 years].

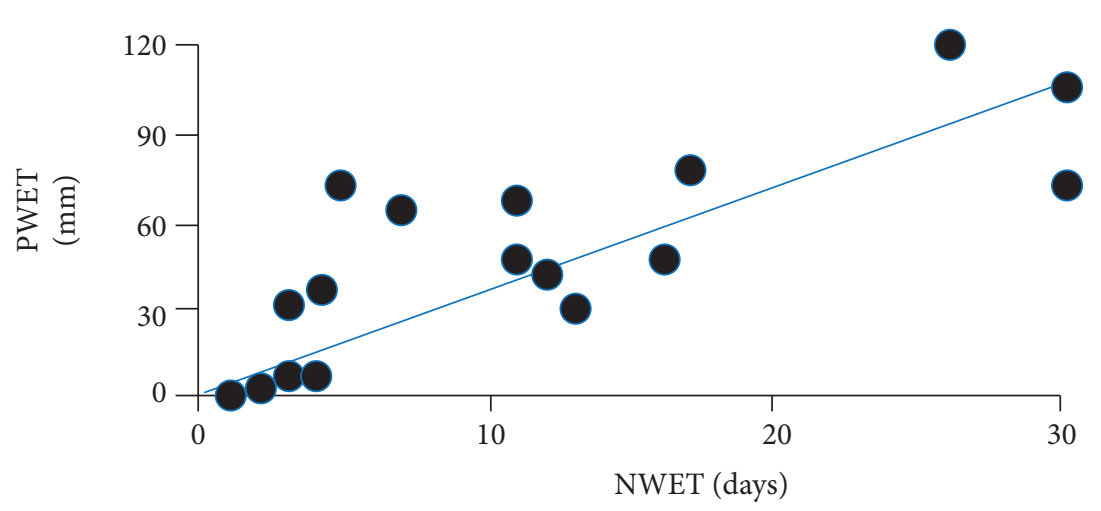

$\mathrm{y}=3.54 \mathrm{x}$

$\mathrm{R}^{2}=0.66$

Figure 4. Dispersion diagram for the values of NWET and PWET. Each circle refers to one year. The regression line considering the intercept $=0$ is drawn in blue. The regression parameters are shown at the upper-left corner. Period: 1979-2016, except 2006 (37 years). 
remains unexplained. Therefore, further studies are needed to determine other factors that could explain the variability of PWET and NWET beyond GRAD and MAG.

Table 2. Pearson correlation coefficients ( $r$ ) between NWET or PWET and NINO3, GRAD, MAG or DIR. Period: 1979-2016, except 2006 [37 years].

\begin{tabular}{|c|c|c|c|c|}
\hline & NINO-3 & GRAD & MAG & DIR \\
\hline NWET & -0.10 & $-0.52^{*}$ & $-0.39^{*}$ & +0.10 \\
\hline PWET & -0.14 & $-0.31^{*}$ & $-0.30^{*}$ & +0.10 \\
\hline
\end{tabular}

*Statistically significant at the 90\% confidence level (absolute value of $r$ above 0.27).

\section{STATISTICAL MODELING}

The theoretical distributions (normal, log-normal, gamma, exponential and Weibull) do not fit the observed distribution of wet days at the adopted level of statistical significance (95\%). Therefore, the sample is restricted to days with exceedance $\geq 1 \mathrm{~mm} /$ day (i.e., daily total $\geq 2 \mathrm{~mm} /$ day). For this new sample, the log-normal distribution with parameters equal to 0.1631 (mean) and 1.326 (standard deviation), as estimated by maximum likelihood method, fits the observed distribution of exceedances $\geq 1 \mathrm{~mm} /$ day for all goodness-to-fit tests ( $\mathrm{AD}, \chi^{2}$ and $\mathrm{KS}$ ) at the $95 \%$ significance level. There is very good visual agreement between the theoretical and observed cumulative distributions (not shown), thus ratifying the results of the goodness-to-fit tests.

The occurrence of wet days with high totals in the dry quarter is not common (Table 1). Wet days with high totals appear in the observed histogram as small frequencies sparsely distributed over the classes with higher totals. The theoretical distribution, therefore, allows the probability of occurrence of higher totals or exceedances to be obtained in a more exact manner.

Based on the log-normal distribution with the estimated parameters, the probability of occurrence of a daily total above a given value computed using Eq. 2 is shown in Fig. 5. The probability sharply decreases as the value increases. The mean number of wet days corresponds to $9.6 \%$ of the days in the quarter $(=8.7 / 91)$, and the mean total in wet days is $3.6 \mathrm{~mm} /$ day $(=31.6 / 8.7)$ (Table 1$)$. The probability of occurrence of days with a total above this mean value is $2.4 \%$. For days with higher totals, such as heavy precipitation days, the probability of occurrence is only $0.5 \%$. Although these days are quite infrequent, there is a clear spatial pattern of convective activity and atmospheric conditions for days with heavy precipitation and deep convection, as will be shown in the next section. For very heavy precipitation days (daily total $\geq 20 \mathrm{~mm} /$ day) (Tank et al. 2009), as the case of 20 October 2011, the probability decreases to $0.2 \%$.

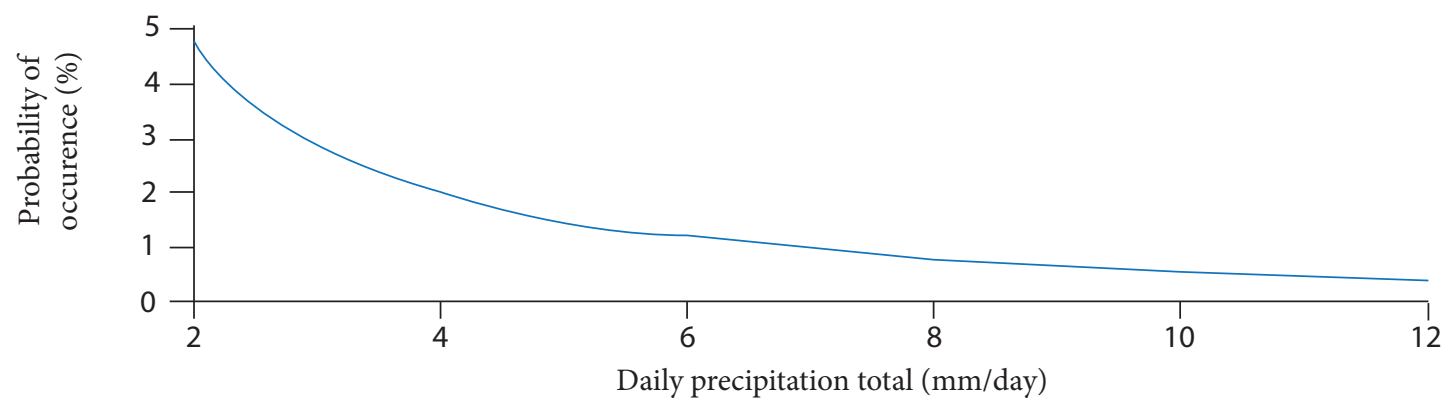

Figure 5. Probability of occurrence [\%, $y$ axis] of a daily precipitation total above a given value ( $\mathrm{mm} /$ day, $x$ axis] based on the log-normal distribution.

\section{CONVECTIVE ACTIVITY AND ATMOSPHERIC CONDITIONS}

In the dry quarter, the average convective activity in tropical South America occurs over a large area along the NW-SE direction that extends from Colombia to central Brazil, passing through the western Amazonia (region A in Fig. 6a). The maximum activity 
in region A is located in northwestern Colombia. The convective activity related to the Intertropical Convergence Zone (ITCZ) affects the North Atlantic Ocean between $5^{\circ} \mathrm{N}$ and $10^{\circ} \mathrm{N}$ (region B in Fig. 6a). Over both regions, A and B, atmospheric conditions that favor the occurrence of deep convection are found: moist layer at $500 \mathrm{hPa}$ (Fig. $7 \mathrm{a}$ ), atmospheric convergence at $850 \mathrm{hPa}$ (Fig. 8a) and divergence at $250 \mathrm{hPa}$ (Fig. 9a). Regions A and B are separated by an area that includes NCB. Over NCB, the OLR values are high $\left(>240 \mathrm{~W} \cdot \mathrm{m}^{-2}\right)$, indicating that deep convection is infrequent and/or not relevant, and atmospheric conditions - dry layer at $500 \mathrm{hPa}$ (Fig. 7a), atmospheric divergence at $850 \mathrm{hPa}$ (Fig. 8a) and convergence at $250 \mathrm{hPa}$ (Fig. 9a) - are opposite to those found over regions A and B. Therefore, in the dry quarter over NCB (and, in particular, over the CLA region), the average atmospheric conditions are consistent with the observed precipitation inhibition.

In days with heavy precipitation and deep convection, the convective activity over region A expands towards NCB, the convective activity over region $B$ expands westward, and deep convection becomes more intense (OLR $\leq 210 \mathrm{~W} \cdot \mathrm{m}^{-2}$ ) over inland areas (such as the eastern Amazonia) and the ITCZ region (Fig. 6b). Over a large area along the South America

(a)

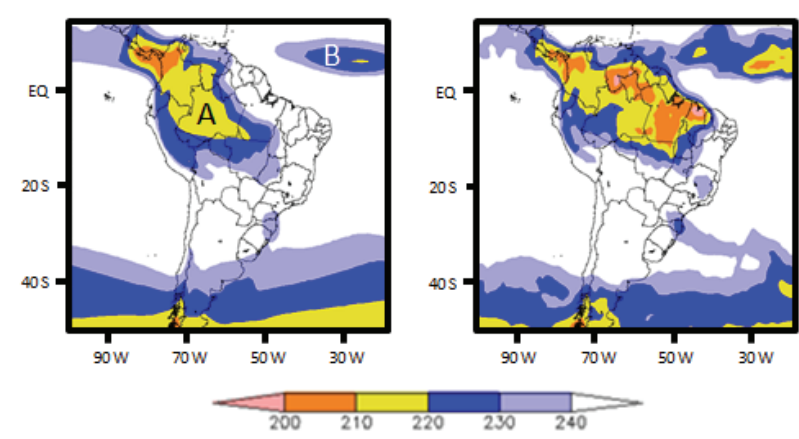

(c)

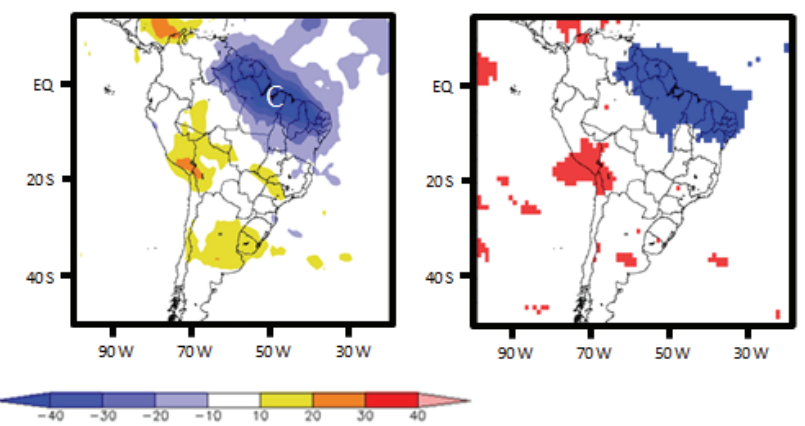

Figure 6. Mean OLR ( $\mathrm{W} \cdot \mathrm{m}^{-2}$ ) (a) for the dry quarter (SON) in the period 1979-2012, (b) for the 15 days with heavy precipitation and deep convection, and (c) the difference between them, i.e., "b" minus "a". (d) Differences are statistically significant at the 95\% confidence level (Student's t-test) over the shaded areas (blue: negative difference; red: positive). "A", "B" and "C" refer to regions described in the text.

(a)

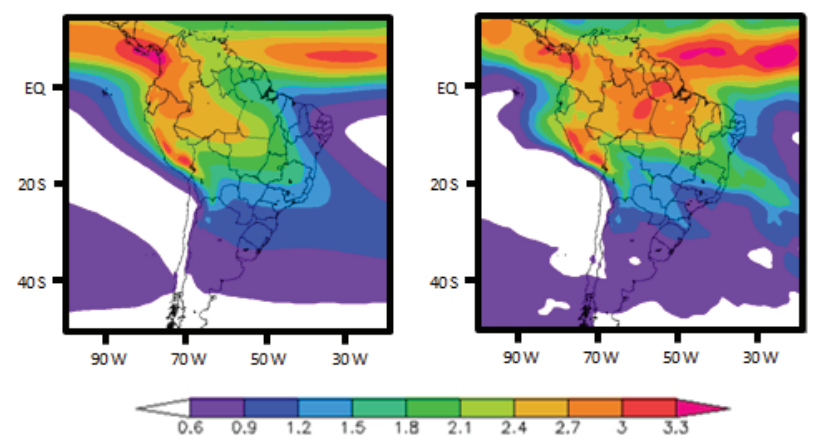

(c)

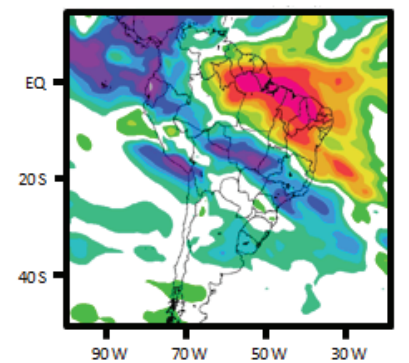

(d)

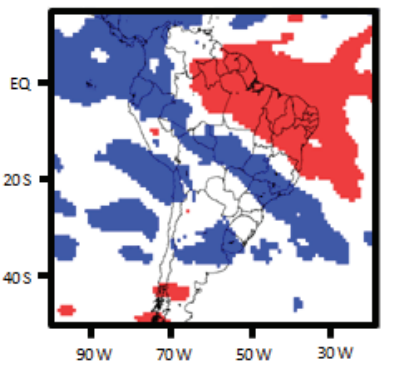

Figure 7. Mean specific humidity at $500 \mathrm{hPa}(\mathrm{g} / \mathrm{kg}$ ) (a) for the dry quarter (SON) in the period 1979-2017, (b) for the 15 days with heavy precipitation and deep convection, and (c) the difference between them, i.e., "b" minus "a". Data from the ERA-Interim reanalysis were used. (d) Differences are statistically significant at the 95\% confidence level (Student's t-test) over the shaded areas (blue: negative difference; red: positive). 
northeastern coast that includes NCB (region C in Fig. 6c), significant OLR differences from the mean are found (Fig. 6d). These differences are negative (Fig. 6c), indicating the onset and/or intensification of deep convection. The spatial pattern of OLR differences in Fig. $6 \mathrm{c}$ is similar to that shown by Oyama and Oliveira (2016) for extreme precipitation events at the CLA region and remains nearly unchanged even when a larger sample of wet days is considered, such as the 42 wet days with above-mean precipitation (daily total $\geq 3.6 \mathrm{~mm} /$ day, i.e., the mean total in wet days) and deep convection $\left(\mathrm{OLR} \leq 230 \mathrm{~W} \cdot \mathrm{m}^{-2}\right)$ (not shown). The horizontal extension of region C indicates that, on days with heavy (or even above mean) precipitation and deep convection in the dry quarter, the convective activity is in general neither isolated nor sparse, but is organized in a well-defined large-scale pattern.

Over region $\mathrm{C}$, there is significant strengthening of favorable conditions for deep convection due to the presence of more moisture at $500 \mathrm{hPa}$ (Fig. 7c), convergence differences at $850 \mathrm{hPa}$ (Fig. 8c), as well as moisture convergence at $925 \mathrm{hPa}$ (not shown) on the continental side, and atmospheric divergence differences at $250 \mathrm{hPa}$ (Fig. 9c). The presence of moisture convergence differences at the lowest tropospheric levels over the NCB agrees with Marques and Souza (2015).

(a)

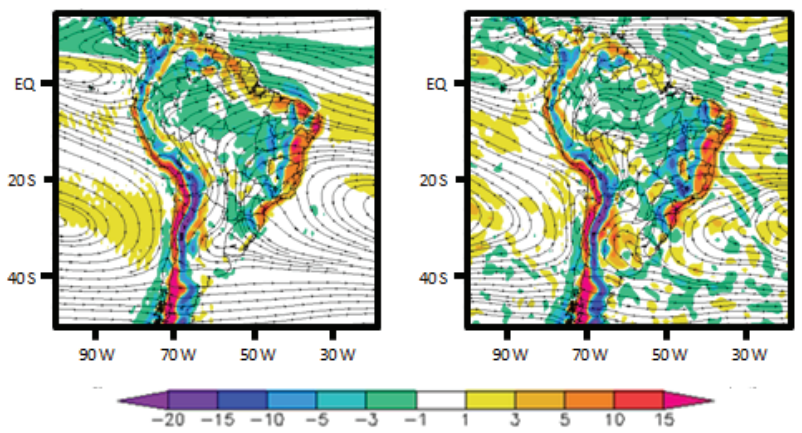

(c)

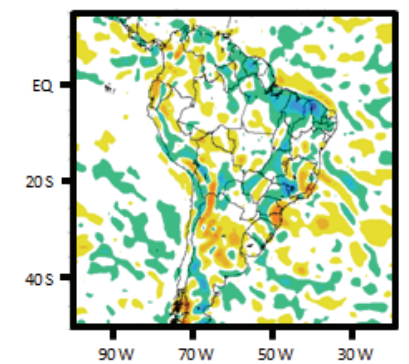

(d)

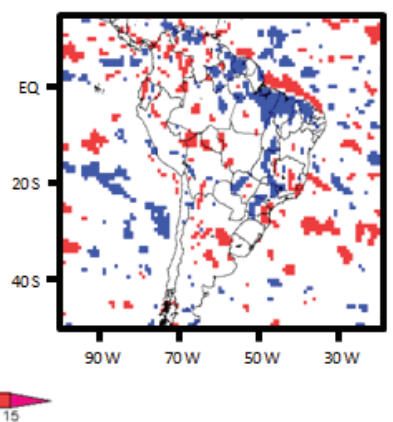

Figure 8. Atmospheric divergence at $850 \mathrm{hPa}\left(10^{-6} \cdot \mathrm{s}^{-1}\right.$ ) (a) for the dry quarter (SON) in the period 1979-2017, (b) for the 15 days with heavy precipitation and deep convection, and (c) the difference between them, i.e., "b" minus "a". Data from the ERAInterim reanalysis were used. (d) Differences are statistically significant at the 95\% confidence level (Student's t-test) over the shaded areas (blue: negative difference; red: positive). (a and b) Streamlines are shown.

(a)

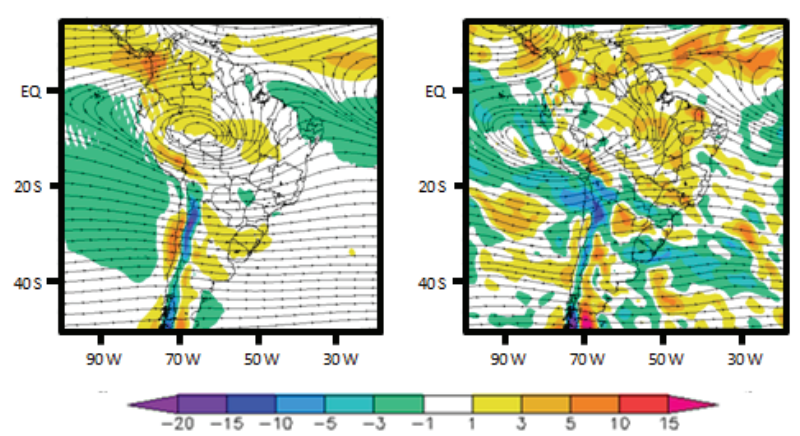

(c)

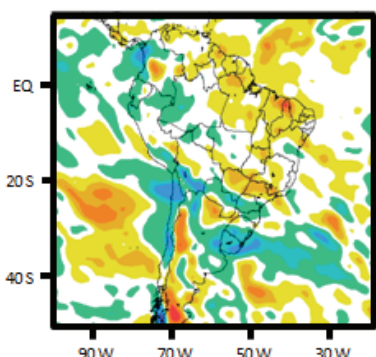

(d)

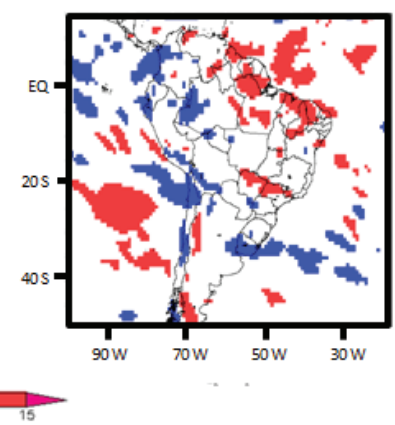

Figure 9. Atmospheric divergence at $250 \mathrm{hPa}\left(10^{-6} \cdot \mathrm{s}^{-1}\right)$ (a) for the dry quarter (SON) in the period 1979-2017, (b) for the 15 days with heavy precipitation and deep convection, and (c) the difference between them, i.e., "b" minus "a". Data from the ERAInterim reanalysis were used. (d) Differences are statistically significant at the 95\% confidence level (Student's t-test) over the shaded areas (blue: negative difference; red: positive). (a and b) Streamlines are shown. 


\section{CONCLUDING REMARKS}

Wet days in the dry quarter $(\mathrm{SON})$ of the CLA region $\left(1^{\circ} \times 1^{\circ}\right.$ area centered at CLA) were addressed in this work. Daily precipitation totals from the CPC/NOAA over the course of 37 years (1979-2016, except 2006) were used. On average, there were 9 wet days, which accumulated $32 \mathrm{~mm}$. These values confirmed those obtained in previous studies based on different and shorter duration datasets (Pereira et al. 2002; Barros 2008; Souza 2013b). Regarding cases with consecutive wet days, the majority (72\%) corresponded to isolated wet days, and the remainder (28\%) was distributed in cases with 2 to 5 consecutive days.

The quarterly precipitation total and number of wet days (PWET and NWET, respectively) showed pronounced interannual variability, confirming the results of Souza (2013b). In general, the time series of PWET and NWET were in-phase and positively correlated $(r=+0.82)$. The inter-annual variability of PWET and NWET was not related to sea surface temperature anomalies (SSTA) in the equatorial Pacific Ocean, confirming Oliveira (2014), or the low-level wind direction over the CLA region, but was significantly correlated with the interhemispheric SSTA gradient in the Atlantic Ocean (GRAD) and the low-level wind speed over the CLA (MAG). Above-mean (below-mean) values of PWET and NWET were related to southward (northward) GRAD and weak (strong) low-level wind over the CLA region. Although this relationship is useful, it did not explain the majority of variance; therefore, further studies are needed to determine other factors that could explain the variability of PWET and NWET beyond GRAD and MAG.

The log-normal distribution with parameters equal to 0.1631 (mean) and 1.326 (standard deviation) fitted the observed distribution of exceedances $\geq 1 \mathrm{~mm}$ /day (i.e., daily totals $\geq 2 \mathrm{~mm} /$ day). Based on this theoretical distribution, the probability of occurrence of a heavy precipitation day ( $\geq 10 \mathrm{~mm}$ /day) was only $0.5 \%$ in the dry quarter.

In the dry quarter, the average convective activity in tropical South America occurred over a large area along the NW-SE direction that extended from Colombia to central Brazil. In days with heavy precipitation and deep convection, this area expanded toward the northern coast of Brazil, leading to negative and significant outgoing longwave radiation differences from the mean over a large area along the South America northeastern coast, including the northern coast of Brazil. This area is similar to that identified by Oyama and Oliveira (2016) for extreme precipitation events in the CLA region. Over this area, there was a significant strengthening of favorable conditions for deep convection due to the presence of more moisture at $500 \mathrm{hPa}$, atmospheric divergence differences at $250 \mathrm{hPa}$ and, on the continental side of the area, convergence differences at $850 \mathrm{hPa}$ and moisture convergence at $925 \mathrm{hPa}$ - this last condition agrees with Marques and Souza (2015). The horizontal extension of the area indicates that, in days with heavy precipitation and deep convection in the dry quarter, the convective activity was in general neither isolated nor sparse, but organized in a well-defined large-scale pattern. The role of transient systems in shaping this large-scale pattern will be addressed in future in-depth case studies, such as that done by Costa (2018).

Regarding the meteorological support in launch missions in the dry quarter, the results of this work indicate that the occurrence of higher precipitation events (unlike the rather unpredictable drizzle or light rain events in the morning) could be predicted. The convective activity organization at larger scales for these events could be helpful for nowcasting, because larger convective systems are more easily tracked in their way to the CLA. Moreover, large-scale atmospheric features for these events could be helpful for short-range weather forecasting, because numerical models are usually more skillful in predicting the evolution of large-scale fields.

\section{ACKNOWLEDGMENTS}

The first author is grateful to the Brazilian Air Force for the opportunity to study at INPE from 2016 to 2017, when this work was carried out. The authors would like to thank the anonymous reviewers for their valuable and constructive comments and suggestions, and Dr. C. A. Sansigolo for his helpful advice on the statistical modeling. 


\section{AUTHOR'S CONTRIBUTION}

Conceptualization, Costa PCS, Oyama MD and Marques RFC; Methodology, Costa PCS and Oyama MD; Investigation, Costa PCS; Writing - Original Draft, Costa PCS; Writing - Review and Editing, Costa PCS and Marques RFC; Supervision, Oyama MD.

\section{FUNDING}

There are no funders to report for this submission.

\section{REFERENCES}

Andreoli RV, Kayano MT (2004) Multi-scale variability of sea surface temperature in the tropical Atlantic. J Geophys Res 109:C05009. https://doi.org/10.1029/2003JC002220

Barros SS (2008) Precipitação no Centro de Lançamento de Alcântara: aspectos observacionais e de modelagem (Master's Dissertation). São José dos Campos: Instituto Nacional de Pesquisas Espaciais. In Portuguese.

Barros SS, Oyama MD (2010) Sistemas Meteorológicos Associados à Ocorrência de Precipitação no Centro de Lançamento de Alcântara. Rev Bras Meteorol 25(3):333-344. https://doi.org/10.1590/S0102-77862010000300005

Calheiros AJP, Machado LAT (2014) Cloud and rain liquid water statistics in the CHUVA campaign. Atmos Res 144: 126-140. https:// doi.org/10.1016/j.atmosres.2014.03.006

Catalunha MJ, Sediyama GC, Leal BG, Soares CPB, Ribeiro A (2002) Aplicação de cinco funções densidade de probabilidade a séries de precipitação pluvial no estado de Minas Gerais. Rev Bras Agrometeorologia 10(1):153-162.

Costa PCS (2018) Precipitação no trimestre seco no Centro de Lançamento de Alcântara: caracterização observacional e estudo de caso (Master's Dissertation). São José dos Campos: Instituto Nacional de Pesquisas Espaciais. In Portuguese.

Coutinho EC, Fisch G (2007) Distúrbios Ondulatórios de Leste (DOLs) na região do Centro de Lançamento de Alcântara. Rev Bras Meteorol 22(2):193-203.https://doi.org/10.1590/S0102-77862007000200005

Dee DP, Uppala SM, Simmons AJ, Berrisford P, Poli P, Kobayashi S, Andrae U, Balmaseda MA, Balsamo G, Bauer P et al. (2011) The ERA-Interim reanalysis: configuration and performance of the data assimilation system. Q J R Meteorol Soc 137(656):553-597. https:// doi.org/10.1002/qj.828

Ferreira NS, Repelli CA, Alves JMB, Souza EB (2005) LOCZCIT - um procedimento numérico para localização do eixo central da zona de convergência intertropical no Atlântico Tropical. Rev Bras Meteorol 20(2):159-164.

Jornal Pequeno (2011) Chuvas provocam alagamentos em ruas e avenidas de São Luís. Jornal Pequeno; [accessed 2017 August 3]. https://jornalpequeno.com.br/2011/10/21/chuvas-provocam-alagamentos-em-ruas-e-avenidas-de-sao-luis/

Lee HT, Schreck CJ, Knapp KR (2014) Generation of the daily OLR climate data record. Presented at: 2014 EUMETSAT Meteorological Satellite Conference; Geneva, Switzerland.

Machado LAT, Rossow WB, Guedes, RL, Walker AW (1998) Life cycle variations of mesoscale convective systems over the Americas. Mon Wea Rev 126(6):1630-1654. https://doi.org/10.1175/1520-0493(1998)126<1630:LCVOMC>2.0.C0;2

Marques VS, Rao VB, Molion LCB (1983) Inter-annual and seasonal variations in the structure and energetics of the atmosphere over northeast Brazil. Tellus 35A(2):136-148. https://doi.org/10.3402/tellusa.v35i2.11427

Marques RFC, Correa FN (2014) A relação do vento com as chuvas no Centro de Lançamento de Alcântara, em anos de El Niño, La Niña e Neutro. Presented at: XVIII Congresso Brasileiro de Meteorologia; Recife, Brazil.

Marques RFC, Fisch GF (2005) As atividades de Meteorologia Aeroespacial no Centro Técnico Aeroespacial (CTA). Bol Soc Bras Meteorol 29(3):21-26.

Marques RFC, Fortes MA (2012) Estudo da variabilidade interanual da precipitação no Centro de Lançamento de Alcântara (CLA). Presented at: XVII Congresso Brasileiro de Meteorologia; Gramado, Brazil.

Marques RFC, Oyama MD (2015) Interannual Variability of Precipitation for the Centro de Lançamento de Alcântara in ENSO-Neutral Years. J Aerosp Technol Manag 7(3): 365-373. https://doi.org/10.5028/jatm.v7i3.477 
Marques RFC, Souza TE (2015) Estudos de Eventos de Chuva no Centro de Lançamento de Alcântara na Estação Seca. Presented at: VI Simpósio Internacional de Climatologia; Natal, Brazil.

Naghettini M, Pinto EJA (2007) Hidrologia estatística. Belo Horizonte: CPRM.

Oliveira PT (2014) Estudo estatístico sobre eventos de precipitação intensa no nordeste do Brasil (PhD Thesis). Natal: Universidade Federal do Rio Grande do Norte. In Portuguese.

Oliveira FP, Oyama MD (2009) Radiosounding-derived convective parameters for the Alcântara Launch Center. J Aerosp Technol Manag 1(2):211-216. https://doi.org/10.5028/iatm.2009.0102211216

Oyama MD, Oliveira GM (2015) O Papel do Entranhamento no Aprofundamento da Convecção sobre a Região do Centro de Lançamento de Alcântara: Estudo Preliminar. Presented at: VI Simpósio Internacional de Climatologia; Natal, Brazil.

Oyama MD, Oliveira GM (2016) Eventos de Precipitação Extrema na Região do Centro de Lançamento de Alcântara. Rev Bras Meteorol 31(4 Suppl):662-674. https://doi.org/10.1590/0102-7786312314b20150157

Pereira EI, Miranda I, Fisch GF, Machado LAT, Alves MAS (2002) Atlas climatológico do Centro de Lançamento de Alcântara. (ACA/RT01/01, GDO-000000/B0047). Instituto de Aeronáutica e Espaço Technical Report.

Pereira RA, Marques RFC (2014) Influência do Atlântico Tropical na precipitação do CLA em anos neutros no Pacífico. Presented at: XVIII Congresso Brasileiro de Meteorologia; Recife, Brazil.

Pinheiro UA, Oyama MD (2013) Rainy season features for the Alcântara Launch Center. J Aerosp Technol Manag 5(4):439-448. https://doi.org/10.5028/jatm.v5i4.266

Sansigolo CA (2008) Distribuiç̃̃es de extremos de precipitação diária, temperatura máxima e mínima e velocidade do vento em Piracicaba, SP (1917-2006). Rev Bras Meteorol 23(3):341-346. https://doi.org/10.1590/S0102-77862008000300009

Santos CAC, Oliveira VG (2017) Trends in extreme climate indices for Pará State, Brazil. Rev Bras Meteorol 32(1):13-24. https://doi. org/10.1590/0102-778632120150053

Silva JC, Heldwein AB, Martins FB, Trentin G, Grimm EL (2007a) Análise de distribuição de chuva para Santa Maria, RS. R Bras Eng Agríc Ambiental 11(1):67-72.

Silva VB, Kousky VE, Shi W, Higgins RW (2007b) An improved gridded historical daily precipitation analysis for Brazil. J Hydrometeor 8(4):847-861. https://doi.org/10.1175/JHM598.1

Souza AS (2011) Condições atmosféricas durante a operação Maracati II. (RT-O2/ACA/R/11). Instituto de Aeronáutica e Espaço Technical Report.

Souza AS (2013a) Condições atmosféricas durante a operação Iguaíba. (RT-01/ACA/13). Instituto de Aeronáutica e Espaço Technical Report.

Souza TE (2013b) Estudo climatológico sobre a ocorrência de precipitação no CLA para o trimestre: setembro, outubro e novembro [Scientific Report). São José dos Campos: Instituto de Aeronáutica e Espaço.

Souza DC (2016) Brisa na costa do norte e nordeste brasileiro (PhD Thesis). São José dos Campos: Instituto Nacional de Pesquisas Espaciais. In Portuguese.

Tank AMGK, Zwiers FW, Zhang X (2009) Guidelines on Analysis of extremes in a changing climate in support of informed decisions for adaptation. Geneva: World Meteorological Organization.

Tavares PS (2008) Um estudo observacional da incursão de sistemas frontais no nordeste brasileiro e sua influência na atmosfera do Centro de Lançamento de Alcântara (CLA) (Master's Dissertation). São José dos Campos: Instituto Nacional de Pesquisas Espaciais. In Portuguese.

Trenberth KE (1997) The definition of El Niño. Bull Amer Meteor Soc 78(12):2771-2778. https://doi.org/10.1175/15200477(1997)078<2771:TDOENO>2.0.C0:2

Xie P, Chen M, Yang S, Yatagai A, Hayasaka T, Fukushima Y, Liu C (2007) A gauge-based analysis of daily precipitation over East Asia. J Hydrometeor 8(3):607-626. https://doi.org/10.1175/JHM583.1

Yang S, Smith EA (2008) Convective-stratiform precipitation variability at seasonal scale from 8 yr of TRMM observations: implications for multiple modes of diurnal variability. J Climate 21(16):4087-4114. https://doi.org/10.1175/2008JCLI2096.1 